Nomura, M.; Azenha, J. - $\bigcirc$ texto como unidade de trabalho

\title{
texto como unidade de trabalho no ensino de línguas e de tradução
}

\author{
Masa Nomura \\ João Azenha*
}

\begin{abstract}
Since the mid 1980's, a paradigm change has taken place in Translation Studies: the primacy of the text to be translated gradually loses terrain to the reception conditions of the translated text. Such a change brought consequences to the concept of translation competence itself: translation students have to be able not only to show a good command of the languages involved, but also to activate other kinds of knowledge, in order to comprehend the text in the source language, and to design translation strategies which enable them to comply with the requirements of the translation task. The article argues that the systematic application of concepts taken from contrastive linguistics research (German/Portuguese), as well as from text linguistics, can help students to improve their knowledge of the foreign language and guide them in their first steps as translators. The theoretical considerations (Part I) are illustrated by an example taken from a translation course (Part II).
\end{abstract}

Keywords: Types of knowledge and text production; acquisition of German as a foreign language; translation competence.

Resumo: A partir de meados da década de 1980, observa-se uma mudança de paradigma na pesquisa sobre tradução: a primazia reservada até então ao texto de partida cede lugar paulatinamente aos fatores que coatuam na recepção do texto traduzido. Tal mudança tem consequiências para a noção de competência tradutória: dos tradutores iniciantes não se espera apenas que tenham bons conhecimentos das línguas com as quais trabalham, mas também que sejam capazes de, na fase de compreensão do texto a ser traduzido, ativarem outras formas de conhecimento e, na fase de retextualização, traçarem estratégias que lhes possibilitem preencher lacunas adequadas à tarefa de tradução. Este artigo visa a demonstrar que a aplicação sistemática de conceitos da pesquisa lingüística de base contrastiva para o par de línguas alemão-português, bem como de conceitos da linguística textual, pode contribuir para que os tradutores iniciantes ampliem e aprofundem seus conhecimentos na língua estrangeira, ao mesmo tempo em que são orientados

\footnotetext{
* Masa Nomura (manomura@usp.br) é professora doutora e João Azenha Jr. (azenha@usp.br) é livre-docente da Área de Alemão, Departamento de Letras Modernas, Faculdade de Filosofia,, Letras e Ciências Humanas, USP
}

Pandaemonium germanicum 14/2009.2, p. 218-242 - www.fflch.usp.br/dlm/alemao/pandaemoniumgermanicum 
Nomura, M.; Azenha, J. - $\bigcirc$ texto como unidade de trabalho

nos primeiros passos da tradução. As considerações teóricas sobre o tema (Parte I) são ilustradas por um exemplo de aplicação (Parte II).

Palavras-chave: Tipos de conhecimento e produção de texto; aquisição de alemão como língua estrangeira; competência tradutória.

Zusammenfassung: Seit Mitte der 80er Jahre hat sich ein Paradigmenwechsel in der Übersetzungsforschung vollzogen: Der bis dahin vorrangig behandelte Ausgangstext tritt nun in den Hintergrund, um den verschiedenen Faktoren Raum zu geben, die bei der Rezeption des übersetzten Textes eine wichtige Rolle spielen. Dieser Wechsel hat Folgen für den Begriff der Übersetzungskompetenz: von angehenden ÜbersetzerInnen wird nicht nur verlangt, dass sie über ausreichende Sprachkentnisse verfügen, sondern auch, dass sie bei der Rezeption des zu übersetzenden Textes andere Wissensbestände aktivieren und bei der Verfassung des Zieltextes Strategien entwickeln, die ihnen ermöglichen, Probleme, die ihnen aus mangelnden Sprachkenntnissen erwachsen, auftragsgemäß zu lösen. Ziel der vorliegenden Arbeit ist es, aufzuzeigen, dass die systematische Anwendung von Konzeptionen der kontrastiven Sprachforschung (Deutsch/Portugiesisch) sowie der Textlinguistik im Übersetzungsunterricht dazu beitragen kann, den Studenten sowohl bei der Erweiterung und Vertiefung ihrer Deutschkenntnisse, als auch im Anfangsstadium ihrer Übersetzerausbildung zu helfen. Die theoretischen Erwägungen (Teil I) werden durch ein exemplarisches Beispiel (Teil II) erläutert.

Stichwörter: Wissensbestände und Textproduktion; Erwerb des Deutschen als Fremdsprache; Übersetzungskompetenz.

\section{Parte I. Uma moldura teórica}

Tanto no ensino de língua estrangeira (LE) quanto no de tradução, tem-se como objetivo contrastar, no trato com o texto de trabalho, não só os mecanismos de funcionamento das línguas-objeto, como também o seu uso contextualizado, que consiste em analisar as funções comunicativas da linguagem e as convenções socioculturais pelas quais se pautam os comportamentos linguísticos em cada comunidade cultural. No caso da tradução, o desconhecimento do mecanismo de funcionamento de cada língua e de seu uso contextualizado se torna um problema quando o aprendiz, ao executar uma tarefa de tradução, tem de lidar com o texto de partida e precisa entendê-lo bem, para então poder

produzir satisfatoriamente o texto de chegada, este também sujeito ao mesmo crivo reflexivo por que passa o texto de partida.

Pandaemonium germanicum 14/2009.2, p. 218-242 - www.fflch.usp.br/dlm/alemao/pandaemoniumgermanicum 
Nomura, M.; Azenha, J. - O texto como unidade de trabalho

A aquisição de LE e a transposição de conteúdos de uma língua para outra são atividades que pressupõem do receptor do texto conhecimentos de vários tipos. A experiência no ensino de tradução mostra que não basta ao aprendiz possuir apenas competência bilíngue. Dele se exige muito mais que o conhecimento meramente gramatical e semântico-lexical do par de línguas em contato. Para alcançar plenamente a compreensão textual, é necessário ativar outras formas de conhecimento - de mundo, de comunidade cultural e de suas convenções, de temas, de gêneros textuais - para, então, na fase de reprodução e de retextualização, possibilitar preencher as lacunas que surgem no processo de transposição de códigos das línguas/culturas em contato.

A unidade de trabalho do professor de língua estrangeira e de tradução é, pois, o texto, considerado na dimensão do seu enraizamento na cultura de origem. Como ponto de partida de nossas reflexões, tomamos como base a noção de texto ao mesmo tempo como estrutura de enunciação - Text auf dem Papier - e como representação mental - Text im Kopf -, tal como conceituado por NUSSBAUMER (1991).

Textos, de uma forma geral, consistem de uma sequência linear de enunciados e de elementos textuais, que se conectam uns com os outros através de recursos próprios da língua, os elementos linguísticos de coesão. A coesão textual sozinha não é suficiente para a apreensão do sentido de um texto, mas é a partir dos elementos coesivos que se chega à coerência: trata-se de um processo contínuo de intercâmbio entre elementos de base semântico-pragmática e elementos linguísticos de superfície, que se alimentam e se realimentam reciprocamente, formando assim as diversas fases de processamento cognitivo. Com base nesses elementos, o leitor vai construindo paulatinamente o sentido do texto. Nesse processo, a estrutura da enunciação (Text auf dem Papier) se transforma na estrutura mental do texto (Text im Kopf). Essa representação mental do texto modifica-se continuamente num movimento de ir e vir associativo e liberta-se pouco a pouco das minúcias do "texto no papel". A linearidade dos elementos linguísticos se dissolve e se transforma em uma estrutura cognitiva multidimensional de sentidos, culminando na constituição do sentido do texto (Textsinn $)^{1}$. A compreensão de texto é, pois, um processo

\footnotetext{
${ }^{1}$ Cf. Linke/Nussbaumer/Portmann 2004, 261-263; Nussbaumer 1991, 129-177.
} 
Nomura, M.; Azenha, J. - O texto como unidade de trabalho

dinâmico e interativo, que ativa vários sistemas de conhecimento armazenados na mente do indivíduo.

\section{Os tipos de conhecimento de que dispomos}

Abordaremos primeiramente o conhecimento linguístico. Todo texto/discurso é realizado através de dado sistema linguístico. Para produzir um texto, necessitamos de conhecimentos gramaticais e lexicais da língua considerada. Isso significa que o falante deve possuir competência linguística, que pressupõe vários tipos de saberes: saber construir uma frase declarativa (enunciação acerca dos fatos do mundo); saber quais regras são necessárias para promover uma pronominalização; saber como as informações da base proposicional (o conteúdo temático) se misturam com o plano de ação e se distribuem ao longo do texto/discurso para constituir as proposições (as menores unidades semânticas de cada oração); saber a partir de que regras se dá a entender ao interlocutor se determinado objeto de que fala o texto já é previamente conhecido dele; saber que unidades lexicais ocupam quais posições na estrutura sintática; saber como as frases são conectadas umas com as outras; saber quais regras fonológicas usar para dar relevância a determinados elementos sintáticos, e assim por diante.

De acordo com a sua função, os tipos básicos de conhecimento linguístico se subdividem em (a) conhecimento linguístico necessário para registro de representações mentais em estruturas sonoras/fonêmicas (classificação de sons e significados) conhecimento de coesão; e (b) o conhecimento linguístico necessário para a constituição do complexo verbal em diferentes níveis - combinação de itens lexicais, conexão de proposições simples em proposições complexas e em estruturas proposicionais conhecimento de coerência.

\section{Conhecimento de conceitos de linguística textual no trabalho efetivo com o texto}


Nomura, M.; Azenha, J. - O texto como unidade de trabalho

Trabalhando com o "texto no papel", o leitor, em primeira instância, busca apreender basicamente, através dos elementos linguísticos nele presentes, as informações pertinentes, que se movimentam no texto em ondas de progressão e retroação, de remissão a elementos do mundo (referência, dêixis, exófora) e do texto (dêixis textual), de estruturação da informação (encadeamento tema-rema), de recuperação ou retomada de alguns elementos já mencionados anteriormente (anáfora, elementos da cadeia tema-rema, pronominalização) e introdução de novas informações (catáfora, elementos remáticos); o leitor procura por elementos de conexão sintático-semântica através de conectores de vários tipos - causais, modais, espaciais, temporais, concessivos - e de itens lexicais relacionados semanticamente entre si (sinônimos, antônimos, hiperônimos, hipônimos, paráfrases) que possibilitem instaurar, constituir e reconstituir os sentidos do texto, até que as partes assim estruturadas o conduzam à compreensão global do mundo construído no texto (Textwelt $)^{2}$.

A produção de texto/discurso faz uso também de recursos semióticos que podem substituir, de forma restrita, alguns recursos do sistema linguístico que os acompanham ou os intensificam. Mímica, gestual e entoação são os recursos paralinguísticos que podem acompanhar os enunciados orais. Na expressão escrita, os objetos icônicos (fotos, desenhos) e a disposição gráfica do espaço concedido ao texto têm a função de ilustrar e explicitar a expressão verbal, ou, em alguns casos, de atribuir a ela uma interpretação peculiar.

\section{Conhecimento da função comunicativo-pragmática do texto/discurso}

A produção do texto/discurso é sempre a realização da intenção de um falante e atende à necessidade de comunicação verbal. Atualiza intenções de indivíduos que agem

2 Cf. Heinemann / Viehweger 1991, 93-103; Nussbaumer 1991, 120-177; Linke/ Nussbaumer/ PORTMANN 2004, 253.

Pandaemonium germanicum 14/2009.2, p. 218-242 - www.fflch.usp.br/dlm/alemao/pandaemoniumgermanicum 
Nomura, M.; Azenha, J. - $\bigcirc$ texto como unidade de trabalho

socialmente. Em seu processo de intercâmbio social, o falante sempre tem intenção de conseguir algo do seu interlocutor. Em ensino de LE, o conhecimento de que, num diálogo qualquer entre interlocutores colocados em determinada situação de comunicação, há sempre uma propósito específico (intenção) e um objetivo a atingir (função pragmática) por parte de cada falante, ajuda o aprendiz a compreender e executar "atos de fala" (ato locucionário, ilocucionário e perlocucionário) ${ }^{3}$, empregando a formulação verbal adequada à situação.

Para o trabalho com o texto, são de particular importância os conceitos de ilocução e perlocução. Quando o falante intenta provocar determinadas reações no receptor, ou quer alcançar determinados estados/objetivos em seu ambiente natural e social, necessita ter à sua disposição conhecimentos acerca de quais enunciados linguísticos em quais situações comunicativas concretas ou em quais estados de coisas pode conseguir realizar determinados objetivos. Esse estado de coisas pretendido só pode ser alcançado se o receptor consegue reconhecer, por intermédio de um texto, o que um falante tem intenção de conseguir, de que forma o interlocutor é envolvido nisso e como este último pode contribuir para alcançar o desejado intento. Em outras palavras, o usuário da língua deve saber formular linguisticamente suas intenções e saber envolver seu interlocutor a fim de conseguir atingir seus objetivos.

\section{Conhecimento de estruturas textuais globais: gêneros textuais- discursivos}

Em ensino de língua, o professor pode decidir sobre qual estrutura textual global pode ser encaixado um tema (uma base proposicional) como, por ex., "acidente de trânsito". Tal tema pode ser tratado sob diversas formas textuais: como narrativa ou relato oral (contar ao interlocutor o fato, o sucedido); como relato do fato para servir como prova

\footnotetext{
${ }^{3}$ Cf. Austin 1962; 1-82; e SeArLe 1981[1969], 1-29; 30-57.
} 
Nomura, M.; Azenha, J. - $\bigcirc$ texto como unidade de trabalho

testemunhal para uma companhia de seguros; como ata protocolada na polícia sobre detalhes do acidente; como reportagem para jornal etc. Conforme os diferentes objetivos de cada formulação textual-discursiva, a base proposicional "acidente de trânsito" é realizada através de diferentes gêneros textuais, que se diferenciam por marcas prototípicas de cada tipo e de cada gênero.

Narrativa, relato, ata e outros gêneros textuais diferenciam-se por princípios específicos de constituição textual, por marcas textuais globais típicas. Trata-se do mesmo conteúdo com funções comunicativo-pragmáticas diferentes. Produtor e receptor devem possuir um conhecimento específico sobre estruturas textuais globais, ter conhecimento de tipologias e gêneros textuais que lhes possibilitem estabelecer textos como exemplares de uma classe. Nosso conhecimento (armazenado) sobre estruturas textuais globais ajuda a explicitar fatores textuais internos e externos presentes no texto. Reconhecemos a existência de um padrão textual (Textmuster $)^{4}$, que fornece o formato característico e os recursos verbais prototípicos do gênero de texto sob análise.

\section{Conhecimento enciclopédico ou de mundo, contexto, interação}

A partir da noção de que o texto constitui um processo ${ }^{5}$, ativa-se mais um tipo de conhecimento responsável pelo processamento textual: o conhecimento enciclopédico ou de mundo. Ele abrange as informações armazenadas na memória de cada indivíduo e compreende o conhecimento declarativo, manifestado por enunciações acerca dos fatos do mundo, e o conhecimento episódico e intuitivo, adquirido através da experiência. Tais conceitos se organizam em blocos e formam uma rede de relações, de modo que um dado conceito evoca invariavelmente uma série de entidades associadas a ele (frames, scripts). O frame "jogo de futebol" evoca, em cadeia associativa sucessiva, uma série de entidades: “clubes”, “jogador”, “camisa de clubes”, “chuteira”, “bola”, “gol”, “apito”, “árbitro”, “torcedor". O conhecimento enciclopédico transforma-se em conhecimento procedimental,

\footnotetext{
${ }^{4}$ Cf. FIX et al. 2002, 105.

${ }^{5}$ Cf. Heinemann/Heinemann 2002: 122; HeinemanN/VIEHWEGER 1991: 93-103.
} 
Nomura, M.; Azenha, J. - $\bigcirc$ texto como unidade de trabalho

que fornece instruções para agir em situações comunicativas específicas (contexto, interação). O conhecimento interacional relaciona-se com a dimensão interpessoal da linguagem e permite a realização de ações por meio da linguagem, subdividindo-se em conhecimento ilocucional (por meios linguísticos diretos e indiretos utilizados para atingir um objetivo), conhecimento comunicacional (uso de meios adequados para atingir os objetivos desejados), conhecimento metacomunicativo (procedimentos de atenuação para evitar distúrbios na comunicação) e conhecimento de superestruturas e modelos textuais globais (conhecimento de tipos e gêneros textuais).

Ao produzir o texto, o produtor apela para sua reserva armazenada de conhecimentos e experiências. $\mathrm{O}$ mesmo faz o receptor, que precisa fazer inferências para preencher as lacunas de conteúdo ${ }^{6}$. A ideia de interatividade que se estabelece entre o produtor e o receptor do texto, ou entre o texto e seu receptor, ganha contornos sólidos, já que é a partir do embate entre os conhecimentos de mundo de ambos os interlocutores (produtor e receptor) que se dá (ou não) a compreensão textual.

A seguir, veremos como essa ideia de interatividade se desdobra e, ao mesmo tempo, se adensa na complexa tarefa de ensinar a traduzir.

\section{Ensinar a traduzir é compartilhar conhecimentos}

Num ensaio intitulado "O ensino da tradução e seus limites: por uma abordagem menos ilusória”, ARroJo $(1992,99)$ relata a seguinte passagem:

Há alguns meses, depois de uma aula de Prática de Tradução no Programa de Bacharelado em Inglês (modalidade tradução) da PUC-SP, uma das alunas me entregou uma lista manuscrita de palavras e expressões inglesas. Explicou-me que essas palavras e expressões haviam sido extraídas de um manual de computação que aceitara traduzir e que, depois de consultar

${ }^{6}$ Cf. Polenz 1988, 302-325.

Pandaemonium germanicum 14/2009.2, p. 218-242 - www.fflch.usp.br/dlm/alemao/pandaemoniumgermanicum 
Nomura, M.; Azenha, J. - $\bigcirc$ texto como unidade de trabalho

vários dicionários bilíngues, alguns deles técnicos, resolvera vir até mim em busca dos significados que tanto ela como os dicionários consultados desconheciam. Quando lhe perguntei, entre irritada e perplexa, porque julgava que eu pudesse lhe oferecer aquilo que até mesmo os dicionários lhe negavam, a aluna, também entre irritada e perplexa, me respondeu que, como responsável por vários cursos de prática de tradução e como especialista da área, eu tinha o dever de conhecer a tradução para o português das palavras e expressões mencionadas.

A partir desse relato, a autora desenvolve sua argumentação tomando por fundamento o confronto, flagrado nesse incidente, entre duas visões opostas: de um lado, a herança de uma abordagem cartesiana, "logocêntrica", como Arrojo a chama, segundo a qual as palavras encerram "significados supostamente mumificados" (p. 103), independentes do contexto em que se encontrem inseridas. Na falta, então, de dicionários completos e infalíveis, a aluna teria se sentido autorizada a apresentar à professora, à responsável pelo ensino de tradução, apenas uma lista de palavras e expressões. De outro lado, Arrojo destaca uma abordagem "menos ilusória (...), que tem como base o questionamento da possibilidade de qualquer significado absolutamente estável ou inerente à palavra ou, em sentido mais amplo, ao próprio texto" (p. 103).

Quase duas décadas são passadas desde a publicação desse ensaio. No entanto, e a despeito do desenvolvimento e da ramificação de muitas áreas dos estudos da linguagem e dos estudos da tradução, a situação descrita parece preservar sua atualidade, ao menos em parte. Afinal, a experiência na sala de aula de tradução ainda aponta para o fato de que a "ilusão do significado estável, mumificado", continua a fazer parte da busca de todos aqueles que, ao se defrontarem com as primeiras dificuldades da tradução, se vêem diante da difícil tarefa não apenas de atribuir sentido, mas também, e sobretudo, de assumir a responsabilidade por ele, mesmo que, muitas vezes, não disponham do tão desejado respaldo de uma fonte fidedigna.

Nessa mesma linha de raciocínio, a experiência também mostra que o mero abandono do aspecto "cartesiano" - motivado por leituras teóricas e discussões em classe, por exemplo - instaura um nível de instabilidade, com o qual os tradutores iniciantes não sabem lidar: ao relacionarem a "nova" perspectiva com a prática de tradução, não raro se observa que os estudantes defendem certo posicionamento em teoria, mas em geral são 
Nomura, M.; Azenha, J. - $\bigcirc$ texto como unidade de trabalho

incapazes de derivar dele um instrumental, a partir do qual possam realizar (e defender) sua tradução. Por sua vez, o ensino de tradução, mesmo ancorado numa perspectiva "menos ilusória”, e que muitas vezes caminha pari passu com o desenvolvimento das habilidades de expressão em língua estrangeira, não pode considerar pressupostos bons conhecimentos da língua estrangeira e da língua materna e prescindir, assim, da perspectiva de interagir com o desenvolvimento dessas habilidades, no sentido de complementar, aprofundar e expandir os conhecimentos de língua (recém-) adquiridos pelos estudantes.

A questão é complexa, pois pressupõe que sejam harmonizados conceitos de diferentes ordens: a noção mesma de como se produzem sentidos em linguagem, a visão de tradução associada a ela e os tipos (e níveis) de conhecimento que precisam ser ativados na operação de traduzir. Além disso, o confronto de visões diferentes, tal como vimos no exemplo de ARROJO (1992), para além de opor concepções atreladas a abordagens sobre tradução fundamentadas filosoficamente ${ }^{7}$, remete também a uma mudança de olhar operada nos estudos da tradução desde meados da década de 1970 e que teve impacto imediato sobre a noção mesma de competência tradutória. No que segue, examinaremos brevemente em que consiste essa mudança de perspectiva e qual seu impacto para a distinção entre competência linguística e competência tradutória. Veremos também que, antes de excludentes, esses dois momentos da história mais recente dos estudos da tradução são complementares e que o espaço da sala de aula de tradução pode se transformar num fórum privilegiado em que visões distintas coexistem e tentam se harmonizar, a fim de que alunos e professores, juntos, possam dar conta de uma tarefa específica.

\section{Uma mudança de olhar}

Desde meados da década de 1950, desenvolveram-se mais sistematicamente os estudos linguísticos de base estruturalista, inspirados no trabalho pioneiro do linguista genebrino Ferdinand de Saussure (1857 - 1913). Quase concomitantemente, assistimos

\footnotetext{
${ }^{7}$ Referimo-nos aqui às duas concepções levantadas por ARROJO (1992) no ensaio citado: a cartesiana, ou logocêntrica, de um lado, e a "menos ilusória", ou desconstrutivista, de outro.
}

Pandaemonium germanicum 14/2009.2, p. 218-242 - www.fflch.usp.br/dlm/alemao/pandaemoniumgermanicum 
Nomura, M.; Azenha, J. - O texto como unidade de trabalho

também ao desenvolvimento dos estudos linguísticos baseados nos trabalhos de Noam Chomsky sobre a gramática gerativo-transformacional. Em ambos os casos, tratava-se de perspectivas teóricas que buscavam uma explicação para a gênese do sentido, fosse pela segmentação dos níveis de análise linguísticos em unidades cada vez menores, fosse pela busca por universais de linguagem situados numa chamada estrutura profunda, a partir da qual se gerava a estrutura de superfície.

O impacto dessas investigações deixou marcas profundas nas teorias de tradução geradas neste período: se fosse possível chegar à determinação de um sentido por uma operação linguística, então também seria possível chegar à identificação de um sentido (quer dizer, de uma leitura consensualmente válida) para os textos. E se isso fosse possível, então, a operação de tradução deveria consistir da determinação desse sentido na língua de partida (ou no "original", para usar um termo próprio dessa fase dos estudos de tradução) e de sua substituição por material linguístico equivalente (CATFORD 1980, 22) ${ }^{8}$ na língua de chegada.

Por volta dos anos de 1980, a visão estruturalista é revista por um grupo de estudiosos a partir de um conceito amplo de cultura, que engloba todas as manifestações do pensamento e do comportamento. Dentro dessa visão, os textos são comparados às folhas de uma árvore (HÖNIG e KuSSMAul 1984), da qual ainda se pode distinguir o tronco e pressupor uma parte "invisível" - as raízes -, responsável pela vida da planta. Para os estudos da tradução daquele período, a metáfora da árvore ajudou a compreender que os textos estão enraizados nas culturas, trazem dela suas características mais fundamentais, delas se nutrem e, nesse sentido, são únicos:

A sociocultura é a raiz de toda manifestação linguística e determina em grande parte sua forma. Quem quiser, portanto, "atacar o problema da tradução pela raiz", não se deve orientar apenas pela parte visível do texto tronco, galhos e folhas, por assim dizer -, mas deve estar em condições de

\footnotetext{
${ }^{8}$ A primeira edição da obra de Catford data de 1965. Para um aprofundamento da questão da equivalência em tradução, tão em voga nesse período, cf., entre outros, CATFORD (1980), KOLLER (1992) e os trabalhos atinentes ao tema contidos em CARDOZO et alii (2009). Numa perspectiva um pouco diferenciada, a questão da equivalência aplicada ao ensino de tradução também está tratada em CoRRÊA e NEIVA (2000).
}

Pandaemonium germanicum 14/2009.2, p. 218-242 - www.fflch.usp.br/dlm/alemao/pandaemoniumgermanicum 
Nomura, M.; Azenha, J. - O texto como unidade de trabalho

avaliar o aspecto geral do texto com base nos pressupostos socioculturais.

(HÖNIG e KUSSMAUL 1984, 45) ${ }^{9}$

Assim, o sentido dos textos estaria associado às peculiaridades de cada cultura, ao modo como cada uma enxerga o mundo e organiza sua experiência. A partir daí, uma simples operação de transcodificação, como a que estava embutida no momento anterior à virada cultural, não daria mais conta do processo, se não fosse acompanhada de adaptações necessárias ao novo modo de ver o mundo na cultura para a qual se traduz. E mais: as novas condicionantes forçaram uma revisão do papel do indivíduo que lê, interpreta e traduz os textos: a operação de traduzir passa a ser uma transferência singular de sentidos gerados na interação do indivíduo com os textos e a depender da finalidade que se tem em mente para o texto traduzido.

Do primeiro momento, voltado retrospectivamente para o texto de partida, resultaram dois efeitos colaterais indesejáveis: de um lado, o caráter normativo e prescritivo das operações de traduzir, seja do ponto de vista do fazer tradutório, seja do da avaliação de traduções; de outro, o fato de que, no interior dessa perspectiva, a competência linguística se confunde com a tradutória: quanto mais se conhece(m) a(s) língua(s) da(s) qual(is) e para a(s) qual(is) se traduz, melhor o resultado da tradução.

Tal perspectiva encontra-se expressa historicamente em dicotomias que marcam os estudos da tradução ao longo do tempo: tradução palavra vs. sentido, tradução literal vs. tradução livre, entre outras. Assim, não é de se estranhar que resquícios importantes dessa orientação estejam presentes, ainda hoje, não apenas na noção mesma de tradução trazida à sala de aula por estudantes iniciantes (como no exemplo apontado no início desta seção), mas também na crítica profissional de tradução, que muitas vezes deposita sobre o léxico seus termos de comparação, confronta soluções de tradução mediadas por dicionários e, não raro, "prescreve" uma solução melhor.

Acompanhando, então, a chamada "virada pragmática" dos estudos da linguagem a teoria dos atos de fala, a sociolinguística, a linguística textual, só para citar alguns exemplos - o olhar se volta do texto de partida para os mecanismos da recepção (situação

\footnotetext{
${ }^{9}$ Salvo indicação em contrário, as traduções das citações são dos autores deste artigo.
} 
Nomura, M.; Azenha, J. - $\bigcirc$ texto como unidade de trabalho

comunicativa, moldura cultural, normas, convenções, comportamentos etc.), bem como para seus agentes (quem pede, quem faz, quem deve receber a tradução), e o processo de tomada de decisões passa necessariamente a ser pautado pela decisão sobre a função que o texto traduzido deverá desempenhar no sistema receptor. Desse modo, outros elementos vêm somar-se à configuração da competência em tradução, que se descola, por assim dizer, da competência linguística: quanto mais se esmiuçarem o perfil do destinatário e as condições de recepção, tanto melhor - ou mais adequada - será a tradução.

Isso, que parece novo, na verdade não o é, e as dicotomias recorrentes na historiografia da tradução são a prova disso: para a tradução literal, temos o correlato da tradução livre; para a tradução palavra por palavra, a tradução pelo sentido. Em suma: uma mudança de orientação rumo ao destinatário da tradução, como a que nos referimos no parágrafo anterior, está presente na historiografia da tradução desde sempre ${ }^{10}$.

Contudo, se a historiografia da tradução ensina que foi entre extremos que se processou toda a linha evolutiva, para a aula de tradução o investimento em apenas um desses extremos pode não ser produtivo. Assim, mesmo operando no interior de uma visão contemporânea, prospectiva e descritiva da tradução, a consideração do texto a ser traduzido e de suas condições de produção continua a ser o ponto de partida por excelência para a definição de uma estratégia de trabalho. E, aqui, as zonas de intersecção com as perspectivas do ensino de língua estrangeira, dos estudos da linguagem e da tradução, podem trabalhar conjunta e produtivamente para a sedimentação de uma concepção de tradução que reconhece e admite diferenças, mas busca tirar proveito daquilo que os opostos têm de melhor para o caso específico.

\section{Parte II. Um exemplo de aplicação}

O exemplo apresentado a seguir visa a ilustrar brevemente a tentativa de harmonizar perspectivas e de, ao mesmo tempo, reforçar as linhas de cooperação entre o ensino de

\footnotetext{
${ }^{10}$ Um exemplo disso são as considerações do orador Cícero (séc. I a.C.) sobre como suplantar seus rivais gregos na mobilização dos ouvintes.

Pandaemonium germanicum 14/2009.2, p. 218-242 - www.fflch.usp.br/dlm/alemao/pandaemoniumgermanicum
} 
Nomura, M.; Azenha, J. - $\bigcirc$ texto como unidade de trabalho

alemão como LE e o de tradução. O trabalho foi realizado com alunos da graduação alemão/português, ainda em fase de aquisição da língua estrangeira: os estudantes tinham, em média, cinco semestres de um estudo sistemático do alemão e, à exceção de alguns poucos, ainda não tinham cursado qualquer disciplina optativa específica de tradução.

O trabalho foi desenvolvido em três etapas: (1) uma etapa de recepção (quer dizer, de compreensão) do texto a ser traduzido, realizada em sala de aula, na qual especial ênfase foi dedicada à ativação de vários tipos de conhecimentos - conhecimentos enciclopédicos, da função comunicativo-pragmática do texto/discurso, de língua, conforme conceituados na Parte I deste estudo - e a partir da qual foram definidas as diretrizes da tradução; (2) uma etapa de retextualização (quer dizer, da redação propriamente dita do texto traduzido), em que a análise do texto de partida e a estratégia de tradução serviram de base para o trabalho individual realizado em casa; e (3) uma etapa de controle (quer dizer, de correção do trabalho), realizada em sala de aula, para a qual se consideraram como elementos balizadores as considerações desenvolvidas na primeira etapa.

O exemplar de texto utilizado, escrito em alemão e em inglês ${ }^{11}$, foi o material de divulgação de uma exposição, em Berlim, da artista plástica búlgara Iva Milanova. Desse prospecto-convite, por assim dizer, que combina texto e imagens, o trecho escolhido para a tradução ao português foi o seguinte:

\section{Quadro 1}

Die in Bulgarien geborene, deutsche Künstlerin Iva Milanova malt mit einem reich modellierten Impasto. Der kräftige Farbauftrag ihrer ikonenhaften Bilder quillt vor Leben und Farbe über. Ihre Palette besonders lebhafter Primär- und Sekundärfarben schreit dem Betrachter mit einer lustvollen Lebensenergie entgegen. In Milanovas prachtvollen Gemälden tut sich eine Welt auf, in der grundlegende Formen neben abstrakten Symbolen stehen, in der Menschen in Muster aufgehen und Muster sich zu Menschen verdichten; Augen entstehen aus gespiegelten Bögen, während konzentrische Kreise zu Pupillen werden. Die Malerin improvisiert mit der Melodie von Form und Farbe und schwelgt in Momenten der Entdeckung,

\footnotetext{
${ }^{11}$ A leitura do folheto informativo não permite dizer qual versão do texto serviu de base à outra. A fim de concentrar a atenção sobre o trabalho com o texto alemão, não será considerada aqui a versão inglesa do texto, à qual os alunos tiveram acesso durante todo o processo descrito nesta seção.
}

Pandaemonium germanicum 14/2009.2, p. 218-242 - www.fflch.usp.br/dlm/alemao/pandaemoniumgermanicum 
Nomura, M.; Azenha, J. - $\bigcirc$ texto como unidade de trabalho

Demontage und spontanen Erkenntnis. Aus einer Vielzahl von Formen schafft sie Bedeutung, die gleichzeitig komplex und auf eine symbolische Art einfach ist. Milanova hat bereits in Deutschland, Italien und den Vereinigten Staaten ausgestellt und wurde auch ausgewählt, um an einer Ausstellung während der Biennale in Venedig teilzunehmen. Sie besitzt Magister-Abschlüsse der Humboldt-Universität $\mathrm{zu}$ Berlin in Kunstgeschichte sowie Archäologie und wurde für drei Jahre an der Kunsthochschule in Sofia ausgebildet. (Agora Gallery, SoHo \& Chelsea, New York).

Na etapa de recepção, compreensão e análise do texto em alemão, os estudantes destacaram dificuldades de diversas ordens e confessaram não saber "por onde começar", nem como hierarquizar os pontos que mereceriam maior atenção.

A fim de organizar e sistematizar o trabalho sugeriu-se uma direção de abordagem em três etapas: (1) da reflexão sobre a inserção do texto numa situação comunicativofuncional para (2) questões de sintaxe e, só então, para (3) as especificidades do léxico. A sugestão levou em conta dois aspectos: em primeiro lugar, incentivar a compreensão do texto como um todo, quer dizer, evitar sua fragmentação imediata em partes desconectadas umas das outras; em segundo, reverter a expectativa tradicional, "herdada", de que as unidades lexicais são depósitos de significados estáveis.

Para tanto, o caminho escolhido foi o da ativação, por redes associativas, de diferentes tipos de conhecimentos. Após uma leitura atenciosa do conjunto, foram discutidas questões atinentes basicamente às artes plásticas (ramo de atuação da artista plástica), à Bulgária (país natal da artista), à Igreja Ortodoxa e ícones (estes últimos motivados pela reprodução de uma tela da artista no prospecto a ser traduzido). Nesta etapa de ativação de conhecimentos de mundo, o objetivo foi concentrar a atenção numa série de conceitos e numa faixa de léxico potencialmente pertinentes ao exercício da tradução. Esta etapa de ativação e de mapeamento de conhecimentos trouxe à baila a necessidade, para a tradução, de se resgatarem e, conforme o caso, de se construírem conhecimentos numa extensão capaz de permitir um tratamento do tema restrito ao âmbito específico da tarefa proposta.

Na sequência, e ainda no interior dessa fase inicial de sensibilização, a discussão se deslocou para a ativação, também por associação, dos conhecimentos da função 
Nomura, M.; Azenha, J. - $\bigcirc$ texto como unidade de trabalho

comunicativo-pragmática do texto/discurso em questão, bem como de sua estrutura global, com destaque para três funções de linguagem nele identificadas: a referencial, a expressiva e a apelativa. Para a tradução, definiu-se como tarefa a elaboração da versão brasileira do texto que apresenta a artista e sua obra.

O primeiro passo foi destacar, no corpo do texto, zonas em que os estudantes percebiam com maior clareza o predomínio de uma ou mais funções. No quadro abaixo, os trechos em itálico apontam para as passagens em que, segundo eles, predomina a função referencial e, os trechos em negrito, para o predomínio das funções expressiva e de apelo:

Quadro 2

Die in Bulgarien geborene, deutsche Künstlerin Iva Milanova malt mit einem reich modellierten Impasto. Der kräftige Farbauftrag ihrer ikonenhaften Bilder quillt vor Leben und Farbe über. Ihre Palette besonders lebhafter Primär- und Sekundärfarben schreit dem Betrachter mit einer lustvollen Lebensenergie entgegen. In Milanovas prachtvollen Gemälden tut sich eine Welt auf, in der grundlegende Formen neben abstrakten Symbolen stehen, in der Menschen in Muster aufgehen und Muster sich zu Menschen verdichten; Augen entstehen aus gespiegelten Bögen, während konzentrische Kreise zu Pupillen werden. Die Malerin improvisiert mit der Melodie von Form und Farbe und schwelgt in Momenten der Entdeckung, Demontage und spontanen Erkenntnis. Aus einer Vielzahl von Formen schafft sie Bedeutung, die gleichzeitig komplex und auf eine symbolische Art einfach ist. Milanova hat bereits in Deutschland, Italien und den Vereinigten Staaten ausgestellt und wurde auch ausgewählt, um an einer Ausstellung während der Biennale in Venedig teilzunehmen. Sie besitzt Magister-Abschlüsse der Humboldt-Universität $z u$ Berlin in Kunstgeschichte sowie Archäologie und wurde für drei Jahre an der Kunsthochschule in Sofia ausgebildet. (Agora Gallery, SoHo \& Chelsea, New York)

Esta primeira etapa permitiu que os estudantes identificassem características fundamentais de grandes áreas do texto como um todo e definissem diferentes fontes de pesquisa, tanto no sentido de confirmarem informações, quanto no sentido de aprofundarem conhecimentos de diferentes naturezas A área destacada em negrito, por exemplo, foi imediatamente identificada como a que demandaria uma ativação mais intensa dos conhecimentos da língua estrangeira. Foi nela, também, que a ausência de informações referenciais possibilitou aos alunos levantarem a hipótese de que ali estariam concentradas

Pandaemonium germanicum 14/2009.2, p. 218-242 - www.fflch.usp.br/dlm/alemao/pandaemoniumgermanicum 
Nomura, M.; Azenha, J. - O texto como unidade de trabalho

as observações valorativas do produtor do texto sobre o trabalho da artista. Para a área destacada em itálico, especial atenção foi reservada ao conhecimento enciclopédico e ao contexto.

Na sequência, e a fim de emigrar para o nível dos conhecimentos de língua alemã propriamente ditos, passou-se a questões de sintaxe, para o que se fez uso de mecanismos de redução das orações a seus componentes essenciais com a eliminação de atributos e modificadores e de destaque para os conectores e elementos de retomada. O quadro a seguir apresenta o resultado dessa etapa. Nele, os componentes essenciais da oração estão destacados em negrito e os mecanismos de relação e de retomada (neste caso, conectores e pronomes possessivos) em itálico:

Quadro 3

Die [...] Künstlerin Iva Milanova malt mit einem [...] Impasto. Der [...] Farbauftrag ihrer [...] Bilder quillt vor Leben und Farbe über. Ihre Palette [...] schreit dem Betrachter mit [...] Lebensenergie entgegen. In Milanovas [...] Gemälden tut sich eine Welt auf, in der [...] Formen neben [...] Symbolen stehen, in der Menschen in Muster aufgehen und (in der) Muster sich zu Menschen verdichten; Augen entstehen aus [...] Bögen, während [...] Kreise zu Pupillen werden. Die Malerin improvisiert mit [...] Form und Farbe und [die Malerin] schwelgt in Momenten der Entdeckung, Demontage und [...] Erkenntnis. Aus [...] Formen schafft sie Bedeutung, die gleichzeitig komplex und [...] einfach ist. Milanova hat $[\ldots]$ in Deutschland, Italien und den Vereinigten Staaten ausgestellt und [Milanova] wurde [...] ausgewählt, um an einer Ausstellung $[\ldots]$ in Venedig teilzunehmen. Sie besitzt MagisterAbschlüsse [...] in Kunstgeschichte sowie Archäologie und [sie] wurde [...] an der Kunsthochschule in Sofia ausgebildet. (...) (Agora Gallery, SoHo \& Chelsea, New York)

O processo de redução aqui demonstrado permitiu à maioria dos estudantes construírem uma espécie de texto-andaime, no qual todo o sistema de relações sintáticas estivesse reconstruído de forma mais simples e mais visível. Com o foco da atenção concentrado 
Nomura, M.; Azenha, J. - $\bigcirc$ texto como unidade de trabalho

nessa estrutura de relações, os estudantes foram solicitados a retomarem a leitura do texto como um todo (preparação para a próxima etapa) ${ }^{12}$.

O passo seguinte consistiu em dar relevância às informações contidas no interior dos atributos e nos advérbios e em identificar as estratégias de condensação de informações em alemão - por exemplo, através do emprego de particípios ampliados e de nominalizações:

Quadro 4

Die in Bulgarien geborene, deutsche Künstlerin Iva Milanova malt mit einem reich modellierten Impasto. Der kräftige Farbauftrag ihrer ikonenhaften Bilder quillt vor Leben und Farbe über. Ihre Palette besonders lebhafter Primär- und Sekundärfarben schreit dem Betrachter mit einer lustvollen Lebensenergie entgegen. In Milanovas prachtvollen Gemälden tut sich eine Welt auf, in der grundlegende Formen neben abstrakten Symbolen stehen, in der Menschen in Muster aufgehen und Muster sich zu Menschen verdichten; Augen entstehen aus gespiegelten Bögen, während konzentrische Kreise zu Pupillen werden. Die Malerin improvisiert mit der Melodie von Form und Farbe und schwelgt in Momenten der Entdeckung, Demontage und spontanen Erkenntnis. Aus einer Vielzahl von Formen schafft sie Bedeutung, die gleichzeitig komplex und auf eine symbolische Art einfach ist. Milanova hat bereits in Deutschland, Italien und den Vereinigten Staaten ausgestellt und wurde auch ausgewählt, um an einer Ausstellung während der Biennale in Venedig teilzunehmen. Sie besitzt Magister-Abschlüsse der Humboldt-Universität zu Berlin in Kunstgeschichte sowie Archäologie und wurde für drei Jahre an der Kunsthochschule in Sofia ausgebildet. (Agora Gallery, SoHo \& Chelsea, New York)

Nesta etapa, a identificação dos recursos empregados para a condensação de informações no pequeno espaço do prospecto teve dois desdobramentos: em primeiro lugar e "retrospectivamente", ela chamou a atenção dos estudantes para a necessidade de cada um rever, na extensão de sua necessidade, tanto a construção dos particípios ampliados em alemão, quanto o emprego de modificadores em geral (por exemplo, os particípios passado e presente, advérbios etc.) e o emprego do genitivo; em segundo, numa perspectiva

\footnotetext{
${ }^{12}$ Sobre o processo de ir-e-vir para a constituição de sentido, cf. as noções de Text auf dem Papier e Text im Kopf, tal como desenvolvidas na primeira parte deste artigo.
}

Pandaemonium germanicum 14/2009.2, p. 218-242 - www.fflch.usp.br/dlm/alemao/pandaemoniumgermanicum 
Nomura, M.; Azenha, J. - $\bigcirc$ texto como unidade de trabalho

prospectiva, os estudantes foram convidados a pensar em formas de acomodação dessas estruturas em português, capazes de dar conta da tarefa de condensação de informações, mas sem prejudicarem a clareza e a legibilidade. $\mathrm{O}$ aspecto contrastivo foi acompanhado, portanto, da preocupação com a recepção e a função do texto traduzido.

Ainda no interior desses atributos complexos, procedeu-se, então, ao destaque para o emprego do léxico específico das artes plásticas [no quadro a seguir, em negrito] e para o emprego inusitado de unidades lexicais, responsáveis pela dimensão "expressiva" do texto. Quanto a este último aspecto, chamou-se a atenção para o estabelecimento, em alemão, de um campo semântico organizado em torno da palavra "Leben" [no quadro a seguir, em itálico].

Quadro 5

Die in Bulgarien geborene, deutsche Künstlerin Iva Milanova malt mit einem reich modellierten Impasto. Der kräftige Farbauftrag ihrer ikonenhaften Bilder quillt vor Leben und Farbe über. Ihre Palette besonders lebhafter Primär- und Sekundärfarben schreit dem Betrachter mit einer lustvollen Lebensenergie entgegen. In Milanovas prachtvollen Gemälden tut sich eine Welt auf, in der grundlegende Formen neben abstrakten Symbolen stehen, in der Menschen in Muster aufgehen und Muster sich zu Menschen verdichten; Augen entstehen aus gespiegelten Bögen, während konzentrische Kreise zu Pupillen werden. Die Malerin improvisiert mit der Melodie von Form und Farbe und schwelgt in Momenten der Entdeckung, Demontage und spontanen Erkenntnis. Aus einer Vielzahl von Formen schafft sie Bedeutung, die gleichzeitig komplex und auf eine symbolische Art einfach ist. Milanova hat bereits in Deutschland, Italien und den Vereinigten Staaten ausgestellt und wurde auch ausgewählt, um an einer Ausstellung während der Biennale in Venedig teilzunehmen. Sie besitzt Magister-Abschlüsse der HumboldtUniversität zu Berlin in Kunstgeschichte sowie Archäologie und wurde für drei Jahre an der Kunsthochschule in Sofia ausgebildet. (Agora Gallery, SoHo \& Chelsea, New York)

Ao isolar faixas de léxico ligadas, de um lado, ao vocabulário específico das artes plásticas e, de outro, a combinações inusitadas (o emprego de metáforas, por exemplo), o procedimento permitiu explorar diferentes tipos de fontes de consulta de forma mais racional. Além disso, ao chamar a atenção para uma dimensão de maior expressividade, esta etapa colocou os estudantes diante da necessidade de eles próprios se afastarem das 
Nomura, M.; Azenha, J. - O texto como unidade de trabalho

acepções consagradas em dicionários, de tomarem decisões que envolviam criatividade e de criarem argumentos que dessem sustentação às suas escolhas.

A seguir, os estudantes foram orientados no sentido de observarem rigorosamente uma sequência de procedimentos para o trabalho de retextualização:

a) reconstrução das amarras sintáticas, tal como proposto na redução do texto alemão [Quadro 3]. Em outras palavras, foi-lhes solicitado reconstruir o texto-andaime alemão, desta vez em português;

b) reflexão sobre alternativas para a condensação de informações em português (a partir do Quadro 4), levando em conta, para isso, o espaço gráfico do prospecto. Especial atenção foi solicitada no sentido de se acomodarem, em português, as informações contidas nos particípios. Num esquema de retroalimentação, foi-lhes solicitado inserir no texto-andaime (item a), acima) as estruturas escolhidas para a acomodação das informações dos particípios;

c) realização de pesquisa específica para o vocabulário das artes plásticas (em especial, da pintura) [Quadro 5, em negrito] e reconstrução das dicotomias apresentadas no texto: "concreto vs. abstrato", "forma vs. símbolo", "humano vs. modelo (padrão)";

d) reconstrução criativa do campo semântico organizado em torno da palavra "vida" [Quadro 5, em itálico] e exploração do aspecto intersemiótico: buscar alternativas de tradução sugeridas pela imagem reproduzida no prospecto.

As três versões intermediárias da tradução, realizadas a partir dos Quadros 3, 4 e 5, foram então refundidas num texto que foi elaborado individualmente e em casa e, depois, discutido em sala de aula. A partir da apresentação dos resultados, ficou claro que os estudantes que se ativeram ao planejamento proposto, isto é, que seguiram rigorosamente a sequência de procedimentos sugerida, foram capazes de redigir textos mais coesos e mais coerentes.

Além disso, o tratamento por etapas das dificuldades de compreensão e de retextualização contribuiu para uma maior consciência no emprego de recursos linguísticos, o que - na opinião dos estudantes - representou ganhos para os conhecimentos de alemão,

Pandaemonium germanicum 14/2009.2, p. 218-242 - www.fflch.usp.br/dlm/alemao/pandaemoniumgermanicum 
Nomura, M.; Azenha, J. - $\bigcirc$ texto como unidade de trabalho

sobretudo no que respeita a tópicos gramaticais pouco explorados até então (neste caso, os particípios ampliados, a organização de um campo semântico, o emprego de metáforas).

Por fim, o trabalho monitorado permitiu um controle a cada etapa e, como consequência disso, uma maior conscientização acerca dos mecanismos de produção de sentido em linguagem, obtida pela interação de diferentes vertentes de pesquisa. O resultado imediato disso foi a construção de argumentos mais sólidos, que auxiliaram os estudantes na defesa de suas opções de tradução, toda vez que essas opções tiveram de se distanciar do apoio de fontes dicionarizadas; toda vez, enfim, em que eles tiveram de se deparar com a dimensão criativa em tradução.

\section{Para concluir: ressalvas e desafios}

O exemplo apresentado acima mostrou não apenas ser possível, mas também produtiva, a combinação de uma perspectiva "retrospectiva", quer dizer, voltada para o texto de partida (suas características e condições de produção) com uma perspectiva "prospectiva", quer dizer, voltada às novas condições de recepção. Assim, sem sugerir uma concentração demasiada em aspectos léxico-semânticos, o que reforçaria uma noção de tradução (e de produção de sentido) herdada e sintonizada com o exemplo da aluna apresentado no início da seção "ensinar a traduzir é compartilhar conhecimentos", a observância de um planejamento, de uma sequência de procedimentos estabelecida em conexão com vários preceitos dos estudos linguísticos, permitiu a reconstrução do texto como um todo, numa estratégia de ir-e-vir, de retroalimentação, capaz de garantir a esse conjunto não apenas sua coesão e sua coerência, mas também sua adequação à tarefa de tradução.

A despeito disso, porém, também foram constatados desvios significativos na reconstrução da dimensão textual-discursiva, conforme demonstra a passagem apresentada a seguir. As opções 1 e 2 de tradução revelam a perda da amarra sintática e as opções 3, 4 e 5, se comprovam a recuperação total ou parcial dessa amarra, também atestam o deslocamento de problemas de tradução para outros níveis da organização discursiva. Os 
Nomura, M.; Azenha, J. - $\bigcirc$ texto como unidade de trabalho

três recursos de destaque - negrito, itálico e sublinhado - visam a facilitar a identificação dos pontos em que os estudantes ou não conseguiram recuperar os trechos correspondentes em alemão, ou só o fizeram parcialmente:

In Milanovas prachtvollen Gemälden tut sich eine Welt auf, in der grundlegende Formen neben abstrakten Symbolen stehen, in der Menschen in Muster aufgehen und Muster sich zu Menschen verdichten; Augen entstehen aus gespiegelten Bögen, während konzentrische Kreise zu Pupillen werden.

[1] Na pintura primorosa de Milanova abre-se um mundo, [?] nas formas básicas estão próximos de símbolos abstratos, predominam nos homens das amostras e amostras ganham formas de homens; olhos transformados a partir de arcos refletidos, enquanto círculos concêntricos são pupilas.

[2] As vistosas pinturas de Milanova abrem-se para um mundo que estão na concretude das formas ao lado do simbolismo abstrato, abre-se nas pessoas como modelo e modelo para transformar as pessoas, os olhos surgem espelhados de arcos ao passo que os círculos concêntricos tornam-se pupilas.

[3] Nas magníficas pinturas de Milanova encontra-se um mundo no qual formas fundamentais estão ao lado de símbolos abstratos; nas quais as pessoas do desenho ficam absorvidas e os desenhos condensam-se em pessoas; olhos resultam de arcos refletidos, enquanto arcos concêntricos tornam-se pupilas.

[4] Nas esplendorosas pinturas de Milanova um mundo se abre no qual formas fundamentais convivem com símbolos abstratos no qual pessoas abrem-se a modelos e se condensam na forma de modelos para as pessoas, olhos são resultado de arcos trabalhados enquanto círculos concêntricos se transformam em pupilas.

[5] Nos magníficos quadros de Milanova abre-se um mundo, onde as formas concretas juntam-se a símbolos abstratos, em que os homens ficam absorvidos nos modelos e estes se consolidam nos seres humanos; aos olhos são dados forma de arcos espelhados e os círculos transformam-se em pupilas.

As opções 1 e 2 apontam, basicamente, para lacunas na elaboração do textoandaime em português a partir do Quadro 3, que foi realizado sob monitoramento em sala 
Nomura, M.; Azenha, J. - $\bigcirc$ texto como unidade de trabalho

de aula. As opções 3, 4 e 5, além de indicarem uma certa frouxidão no tratamento do textoandaime, também parecem apontar para um tratamento indevido das questões de acomodação das informações do texto alemão em mecanismos de condensação adequados em português, de um lado, e a um descuido proporcional no que respeita, sobretudo, à recriação do campo semântico.

A constatação desses desvios poderia ser minimizada pela observação de que, numa classe de cerca de vinte alunos, nem todos apresentam um mesmo nível de resposta às sugestões propostas pelo professor. Afinal, se por falta de disciplina, ou se confiando que a mera substituição de palavras num trabalho linear fosse dar conta das dificuldades, os resultados apresentados acima demonstram que os estudantes não dedicaram atenção e tempo suficientes a etapas específicas da retextualização, capazes de garantir ao resultado coesão e coerência. O dado positivo, neste caso, é o de que o tipo de desvio na tradução aponta necessariamente para uma etapa específica e não cumprida a contento no processo de retextualização, isto é, o tipo de desvio aponta para uma lacuna específica que, em cada caso, precisa ser preenchida.

Ao mesmo tempo, a relativa falibilidade do procedimento, detectada em alguns casos, pode apontar para, pelo menos, dois outros desafios. O primeiro diz respeito aos estudantes e sugere que a reversão de expectativa dos tradutores iniciantes, no que respeita à noção de tradução enquanto trabalho linear com foco no léxico e no uso de fontes dicionarizadas bilíngues, não se dá a partir de uma única tomada de consciência, num único exercício vivenciado, mas ao longo do tempo e com a observância sistemática e monitorada de um procedimento. Um correlato, na prática, para o que se tem observado, como dissemos, nas aulas de teoria da tradução. O segundo volta-se aos professores e aos cursos de tradução. No interior de uma experiência interativa, há muito ficou para trás a figura do professor-tradutor que, com sua experiência, transforma a aula ou num conjunto de dicas sobre como traduzir (bem), ou então num anedotário de situações sobre como traduzir (mal). Vista sob a ótica da construção de conhecimento, a tradução impõe aos que monitoram esse aprendizado, cada vez mais, o desafio de dominar, em diferentes extensões, conceitos de áreas afins; o desafio, enfim, de construir metodologias adaptáveis às mais 
Nomura, M.; Azenha, J. - $\bigcirc$ texto como unidade de trabalho

diversas situações. Este desafio é o correlato, na prática da aula de tradução, para a noção, amplamente aceita em teoria, da tradução como uma área inter e transdisciplinar.

\section{Anexo}

\section{Iva Milanova}

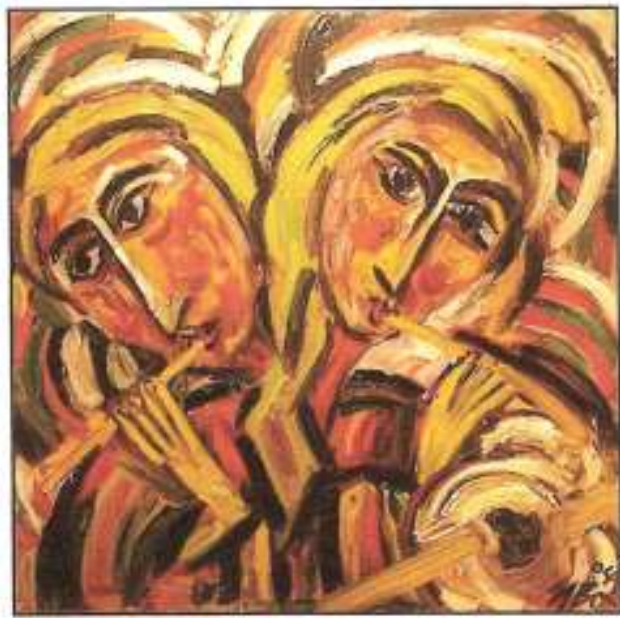

"La Bocca e la Verità“ Malerei

$16.12 .2005-12.02 .2006$

\section{Iva Milanova}

Da h Buperlen pabcrens, deutsche Kinetlerin Wa Mtanove mait met einem roich modellierten Impasto. Der krabitige Farbauttrag itrer ivonanhahtan Bloser quilt vor Leben und Fabe cber. thre Palatte

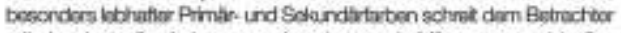
mit echer kustuden Lebensonergie entgegen. in Miluroves practituolon Gemilden tut sich eine Wait auf, in dor gurndlogende Formen noben abstrakten Symbolan stiphan, in der Menschen in Mustor aufpehon und Muster scch zu Mensechen verdichlon; Augen entstehen aus gespiegeben BXgon, watrend koneentrische Krese zu Puplen werden. Die Melerh improvisiart mit der Melode von Form und Ferbe und sctiwedst in Momenten der Eritdeckurg, Derrontage und spontanen Erwenntrits. ALts efiner Veizahl von Formen scham sie Beseuturg, dia gikichreitig komplex und aut ene smbolische Avt einfech ist, Mlanova hat berats in Deutschiend, ltaken und den Vereinigfen Streten susgestelt und wurda such avagewathit, um en ciner Aussieling wahrend der Biksnnole in Vanedig telizusahmen. Sie besitzt Mapigter-Abechiüsese cer Humbokat - Unhorstat zu Berth hi Kunstgoschich to sowie Archibologet und wurde fưr dres Jehre an der Kunsthochechuid in Sola ausgebiddet. ugora Galery, Sotio s: Chotsea, New Yonle

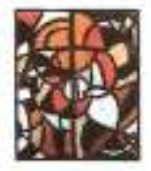

Buigarian-bom Gorman artiat lua Mlanova bra down a nctiby texturod impesto. Her thickly painted ioco ladern warles brim with life and coloce. Espaciality acthe, hor peletto of prinary arnd secondery color shouts out to viewers with a lusty anergy for ife. Meinnova's aplendid imagon compare besic shepes to abatract symbols. it is an inter-reiated work Whare peocla become pattem and voo-versa. Eyes are lomed from mincued arcs and co-contric cirdes beconns puplts. Hars is a musical improstsation of form and colkr. It basks in moments of discovery. clisssarthly, and retantaneous recogition. Through a range of torns she builds both correlex and simple symbclic mearing. Mianova has shown in Gormany, itryy and in the Uniled Statos, and tos abo beer chosen to participate in a exdivition during the Verice Bicrnale. Shat obtained degrees in ert history and archeology from the HumboldtUrmeraky in Berin and wes educated at the Unwersity of Arts in Solia for three years. (Agora Gallory, Solto \& Cheison, New York)

\section{ART CENTER BERLIN FRIEDRICHSTRASSE \\ 10117 Berlin-Mitte, Friedrichstrabe 134, gegenūber Friedrichstadtpalast \\ S-M-Bht. FriedrichstraBe oder U-Bht. Oranienburger Tor} Tel. 030/27 B7 90 20, www.art-center-berlin.de 
Nomura, M.; Azenha, J. - O texto como unidade de trabalho

\section{Referências bibliográficas}

Arrojo, Rosemary. O ensino da tradução e seus limites. In: Arrojo, Rosemary (org.). $O$ signo desconstruído. Implicações para a tradução, a leitura e o ensino. Campinas (SP), Pontes, 1992, 99-105.

Austin, John L. How to Do Things with Words. Oxford, 1962.

CArdozo, Maurício / Heidermann, Werner / Weininger, Markus J. (eds.). A Escola Tradutológica de Leipzig. Frankfurt a.M., Peter Lang, 2009.

CATFORD, John Cunnison. Uma teoria lingüística da tradução. Trad. do Centro de Especialização de Tradutores do Inglês do Instituto de Letras da PUC-Campinas. São Paulo, Cultrix; Campinas (SP), PUC, 1980. [1ª ed.1965]

CorrêA, Angela Maria da Silva / NeIVA, Aurora Maria Soares. Estratégias e problemas do tradutor aprendiz: uma visão introspectiva do processo tradutório. In: MoNTEIRO, Maria José Pereira. Práticas discursivas: instituição, tradução e literatura. Rio de Janeiro, UFRJ, Faculdade de Letras, 2000, 34-52.

FIX, Ulla / PoETHE, Hannelore / Yos, Gabriele. Textlinguistik und Stilistik für Einsteiger. Ein Lehr- und Arbeitsbuch. Frankfurt am Main etc., Peter Lang, 2002.

HeInemann, Margot/ / HeInEMAnN, Wolfgang. Grundlagen der Textlinguistik. Interaktion - Text - Diskurs. Tübingen, Niemeyer, 2002.

Heinemann, Wolfgang; VieHWEger, Dieter. Textlinguistik. Eine Einführung. Tübingen, Niemeyer, 1991.

HönIG, Hans G. / Kussmaul, Paul. Strategie der Übersetzung. Ein Lehr- und Arbeitsbuch. 2., durchgesehene Aufl. Tübingen, Narr, 1982.

KolLER, Werner. Einführung in die Übersetzungswissenschaft. 4., völlig neu bearb. Aufl. Heidelberg, Wiesbaden, Quelle \& Meyer (UTB 819), 1992.

Linke, Angelika / Nussbaumer, Markus / Portmann, Paul R. Studienbuch Linguistik.5., erweit. Aufl. Tübingen, Niemeyer, 2004.

Nussbaumer, Markus. Was Texte sind und wie sie sein sollen. Ansätze zu einer sprachwissenschaftlichen Begründung eines Kriterienrasters zu Beurteilung von schriftlichen Schülertexten. Tübingen, Niemeyer, 1991.

PolEnZ, Peter von. Deutsche Satzsemantik. Einführung in Grundbegriffe des Zwischenden-Zeilen-Lesens. 2., durchges. Aufl. Berlin, Sammlung Göschen, 1988.

SEARLE, John R. Os actos de fala. Um ensaio de Filosofia da Linguagem. Coimbra, Livraria Almedina, 1981. [Speech Acts. Cambridge, Cambridge University Press, 1969.] 